\title{
Endothelial Cells, Ankaferd Hemostat, and Estradiol
}

\author{
Endotel Hücreleri, Ankaferd ve Estradiol
}

\author{
Yasemin Ardıçoğlu1, Nejat Akar¹, İbrahim Haznedaroğlu2 \\ ${ }^{1}$ TOBB-ETÜ Hospital, Ankara, Turkey \\ 2 Hacettepe University Faculty of Medicine, Department of Hematology, Ankara, Turkey
}

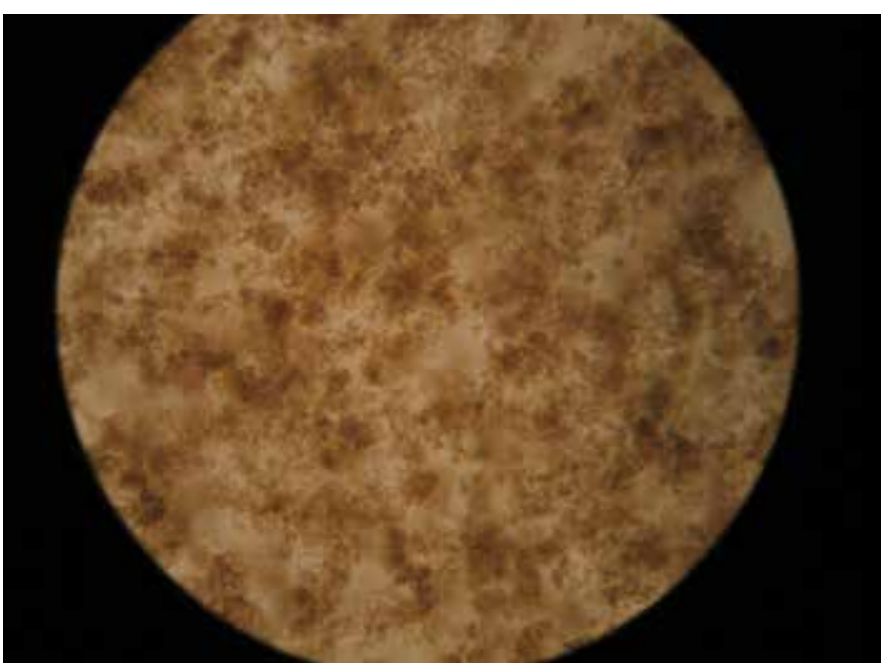

Figure 1A. A. Human umbilical vein endothelial cells adhered to each other, within seconds, just after the application of Ankaferd hemostat $(5 \mu \mathrm{L})$.

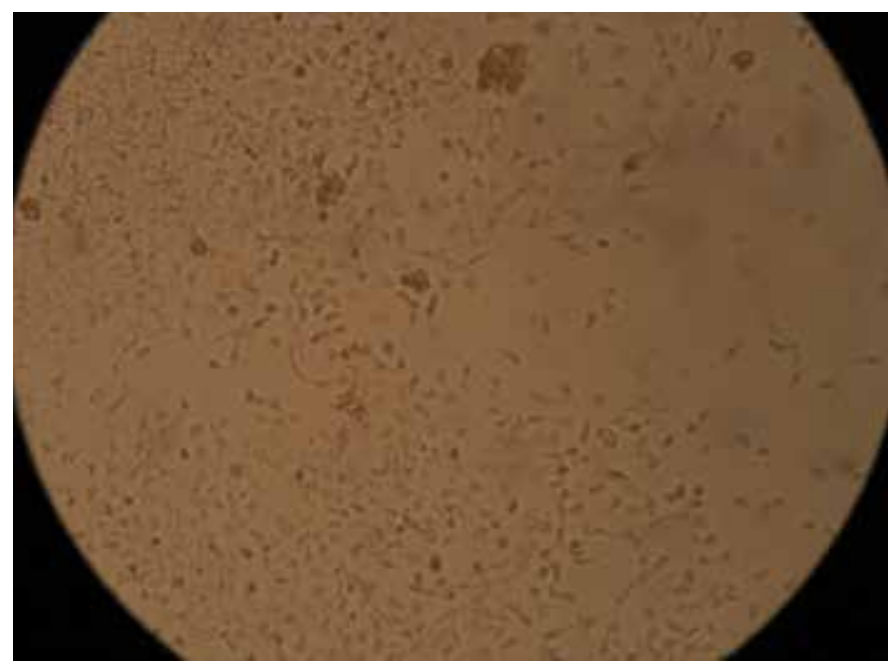

Figure 1B. Reversible vital endothelial cell adherence/aggregation in human umbilical vein endothelial cells $24 \mathrm{~h}$ after application of Ankaferd hemostat $(5 \mu \mathrm{L})$.
We previously demonstrated the effects of Ankaferd hemostat $(\mathrm{AH})$ on human umbilical vein endothelial cells (HUVECs) in Turkish Journal of Hematology [1]. Endothelial cells adhered to each other within seconds and critical intracellular transcription factors were activated just after the application of $\mathrm{AH}(5 \mu \mathrm{L})$ to the HUVECs (Figure 1A). Rapid vital endothelial cell adherence/ aggregation is reversible and could be reversed within $24 \mathrm{~h}$ (Figure 1B).

We further determined that the cellular effects of AH on HUVECs are clinically important in pharmacobiological hemostasis $[1,2,3]$. Endothelial cells are involved in a range of pathophysiological processes including hemostasis, inflammation, and angiogenesis [4], all of which are directly related to the effects of $\mathrm{AH}[1,2,3]$. However, the relevant receptors on the surface of HUVECs and the molecules inside the content of $\mathrm{AH}$ affecting the endothelial cells remain unknown. Since HUVECs express estrogen receptor (ER) beta [4] and rapid HUVEC cellular responses to estrogen can be mediated by estrogen binding to ER [5], we herein aimed to investigate the estradiol content of $\mathrm{AH}$. Estradiol concentration is found to be very high in $\mathrm{AH}(1452.6 \mathrm{pg} / \mathrm{mL})$, whereas progesterone level is $6.06 \mathrm{ng} / \mathrm{mL}$. Those results suggest novel hypotheses that shall be tested in future investigations regarding the interrelationships of vascular endothelial cells, hemostasis, and estradiol inside $\mathrm{AH}$.

Keywords: Endothelium, Ankaferd, Estradiol

Anahtar Sözcükler: Endotel, Ankaferd, Estradiol

\section{Authorship Contributions}

Concept: İbrahim Haznedaroğlu, Nejat Akar; Design: Yasemin Ardıçoğlu, Nejat Akar, İbrahim Haznedaroğlu; Data Collection 
or Processing: Yasemin Ardıçoğlu, Nejat Akar, İbrahim Haznedaroğlu; Analysis or Interpretation: Yasemin Ardıçoğlu, Nejat Akar, İbrahim Haznedaroğlu; Literature Search: Yasemin Ardıçoğlu, Nejat Akar, İbrahim Haznedaroğlu; Writing: Yasemin Ardıçoğlu, Nejat Akar, İbrahim Haznedaroğlu.

Conflict of Interest: The authors of this paper have no conflicts of interest, including specific financial interests, relationships, and/or affiliations relevant to the subject matter or materials included.

\section{References}

1. Yılmaz E, Güleç Ş, Torun D, Haznedaroğlu ic, Akar N. The effects of Ankaferd $^{\circledR}$ Blood Stopper on transcription factors in HUVEC and the erythrocyte protein profile. Turk J Hematol 2011;28:276-285.
2. Karabiyik A, Güleç S, Yilmaz E, Haznedaroglu I, Akar N. Reversible proteaseactivated receptor 1 downregulation mediated by Ankaferd Blood Stopper inducible with lipopolysaccharides inside the human umbilical vein endothelial cells. Clin Appl Thromb Hemost 2011;17:165-170.

3. Karabıyık A, Yılmaz E, Güleç S, Haznedaroğlu I, Akar N. The Dual Diverse Dynamic Reversible Effects of Ankaferd Blood Stopper on EPCR and PAI-1 Inside Vascular Endothelial Cells with and without LPS Challenge. Turk J Hematol 2012;29:361-366.

4. Toth B, Saadat G, Geller A, Scholz C, Schulze S, Friese K, Jeschke U. Human umbilical vascular endothelial cells express estrogen receptor beta (ER $\beta$ ) and progesterone receptor A (PR-A), but not ER $\alpha$ and PR-B. Histochem Cell Biol 2008;130:399-405.

5. Russell KS, Haynes MP, Sinha D, Clerisme E, Bender JR. Human vascular endothelial cells contain membrane binding sites for estradiol, which mediate rapid intracellular signaling. Proc Natl Acad Sci U S A 2000;97:59305935. 